\title{
How the Income Elasticity of Meat Consumption differs between social groups? A case of the UK and the Czech Republic
}

\author{
Jindřich Špička ${ }^{1}$, Jane Eastham², Markéta Arltová ${ }^{3}$ \\ ${ }^{1}$ Faculty of Business Administration, Prague University of Economics and Business, Czech Republic \\ ${ }^{2}$ Harper Adams University, United Kingdom \\ ${ }^{3}$ Faculty of Finance and Accounting, Prague University of Economics and Business, Czech Republic
}

\begin{abstract}
The purpose of the article is to show different consumer behaviour between ten different income levels (deciles) and different countries and to examine the elasticity distance between income deciles in the UK (a high-income country) and the Czech Republic (a low-income country) within the context of meat consumption. The official statistic services provided data in the Czech Republic (Czech Statistical Office, 2020) and the UK (Office for National Statistics, 2020). Data on the Czech Republic come from the household budget surveys (HBS). In contrast, corresponding data on UK consumers was drawn from the Living Costs and Food survey, which succeeded the National food survey and household expenditure survey. Both sets of data were set according to households' structure from the EU-SILC Survey (national module of the European Union - Statistics on Income and Living Conditions). To estimate the income elasticity of meat in the Czech Republic and the United Kingdom in different consumer income groups, a time series cointegration analysis was applied to analyse the annual data for 2000-2017. The Törnquist equation and the difference between income elasticity in monetary and natural expression show saturation and preference of high quality meat in the higher-income consumers in the UK than the same groups in the Czech Republic and overall increasing demand for quality in other income groups. The results support the theory of nutrition transitions. The value of the research is that it would enable the exploration of the potential impact and nature of fiscal interventions for improving diets whilst enabling food producers to forecast meat consumption within the different customer segments.
\end{abstract}

\section{Keywords}

Price elasticity, income elasticity, meat consumption, saturation limit.

Špička, J., Eastham, J. and Arltová, M. (2021) "How the Income Elasticity of Meat Consumption differs between social groups? A case of the UK and the Czech Republic", AGRIS on-line Papers in Economics and Informatics, Vol. 13, No. 4, pp. 101-117. ISSN 1804-1930. DOI 10.7160/aol.2021.130409.

\section{Introduction}

Livestock production is an important agricultural activity in the EU with some 45.2 million tons of meat produced across the 28 member states, which for the UK alone, represent $55.7 \%$ of all agricultural income (Cook, 2018). Meat remains an essential source of agri-business and food business income and essential use of land.

An examination of consumption trends shows significant variation between Lesser Economically Developed Countries (LEDCs) and More Economically Developed Countries (MEDCs). Such trends can be attributed variously; not least to income variations stimulated by economic, political and social change. For instance, after 1990, following the fall of the Soviet Union, Central-and Eastern European countries per capita consumption of meat increased. Further increases per capita were evident in many of these countries following their entry into the EU in 2004; Czech Republic households showed stronger demand for higherquality meat. Also, increased purchasing power made many Czech households more concerned as to product quality and content than under previous regimes (Euromonitor International, 2018).

Yet from the supply side, with the fall of the Eastern Block, Czech Republic meat producers and processors were faced with increased competition from new market entrants from western Europe. These events led to greater market concentration within the meat processing 
sectors (Blazkova, 2016; Spicka, 2016), and a further reduction in their self-sufficiency in pork and poultry.

The situation in meat production and processing varies across Central European countries. The Czech Republic is surrounded by highly concentrated meat processing capacities in Germany and Poland. Poland is one of the top five producers of pork and poultry meat in the European Union. German meat processing capacities are in top-five ranking in beef, pork and poultry meat. Meat processing capacities in Austria are not so concentrated, but they are remarkable for high technology and labour productivity (Marquer, Rabade and Forti, 2015). Consequently, the policymakers, meat producers and producers need to find a way to promote indigenous production and convince customers to buy higher-quality meat products of Czech origin.

Income elasticity is an important determinant of consumer behaviour and is worth greater investigation. The benefits of improving selfsufficiency in the Czech Republic are both economic and social. The solutions can be seen to be in the hands of the policymakers, meat producers and producers.

The UK is similarly faced with a lack of selfsufficiency in meat production areas and is $>72 \%$ self-sufficiency in poultry and $>60 \%$ in pork. In conditions, of uncertainty in the political upheaval following Brexit may be faced with preferential trade agreements with the US, which could further threaten the self-sufficiency of the UK meat sector.

Demand-side and the factors affecting meat choice in the UK can be distinctive from the Czech Republic. The decline in meat consumption in the home and changes to consumption patterns have been linked to various factors such as consumer concerns over the impact of animal production on greenhouse emissions, animal welfare and concerns over the meat consumption on human health (Melina, Craig and Levin, 2016; Santeramo et al., 2018). Essential suggestions have been made within nutritional guidelines that encourage consumers to eat less meat, mainly processed meat products.

The meat production and patterns differ between the Czech Republic and the UK. British consumers prefer more beef and veal (11.4 kg per capita, 2019) and sheep meat (3.9 $\mathrm{kg}$ per capita, 2019) than the Czech consumers $(9.1 \mathrm{~kg}$ beef and veal per capita, 2019; $0.4 \mathrm{~kg}$ sheep meat per capita,
2019). On the contrary, Czech consumers prefer pork meat (43 kg per capita, 2019) much more than British consumers (16 kg per capita, 2019). The consumption of poultry meat does not significantly differ between the Czech Republic and the UK (OECD, 2020; Czech Statistical Office 2020; meat consumption is measured in thousand tonnes of carcass weight). The differences are rooted in the history. Beef and sheep farming has a long tradition in the UK while large intensive pig farms has been typical type of farming in the Czechoslovakia since $50 \mathrm{~s} / 60 \mathrm{~s}$ of the $20^{\text {th }}$ century.

In the UK, beef is more consumed in the UK than a decade ago due to population growth. Nevertheless, per capita consumption remains relatively flat with any reduction yet to show in annual per capita figures. Sheep-meat (mostly lamb) consumption has seen a gradual decline in the UK for some time due to limited cooking versatility and a perceived higher price point. "Although consumption has trended down 10\% in the last decade, it is still much higher in the UK on a per capita basis than in many other developed nations, a legacy of the historic importance of the wool trade within Britain's economy. Today consumers benefit from a highquality product being readily available locally" (Norton, 2020). Increasing productivity of pork and poultry farms reduced the production costs and price of pork and poultry meat and make them more affordable for Britons and partially substituted some of the beef and lamb within consumers' baskets (Norton, 2020).

In the Czech Republic, pork meat consumption is relatively stable in the recent years. The beef meat consumption has been slightly increasing in the recent years but it is much lower than before 1990. The total production of beef in the Czech Republic has long exceeded domestic consumption (Ministry of Agriculture, 2020). The popularity of the poultry meat has increased in the Czech Republic for a long time but the Czech Republic is not self-sufficient in the poultry meat production. The main reasons why the consumption of beef meat dropped and the popularity of poultry meat increased in the Czech Republic in the last thirty years are dietary concerns (consumers prefer poultry meat to red meat) and price relations (poultry meat became cheaper due to large-scale production and the price pressure of foreign production).

Research suggests that dietary change can be facilitated through prices and taxation schemes and health food subsides (Niebylski et al., 2015). Taxation of unhealthy food increases food prices 
and changes consumer preferences towards healthier food. Unhealthy food taxes and healthy food subsidies should be a minimum of 10 to $15 \%$ and preferably used in tandem (Smed, Jensen and Denver, 2007). In their systematic literature review, Thow et al. (2010) confirmed that taxes and subsidies influenced consumption in the desired direction, with larger taxes being associated with more significant changes in consumption, body weight and disease incidence. This conclusion is relevant for multiple-nutrient studies which allowed for substitution between different kinds of food. However, other studies suggested that a single target food would as extant research had failed to appreciate that consumers would simply switch to alternative foods.

Indeed, previous research suggests that different socio-economic and demographic groups respond differently to any price adjustment as a consequence of taxation (Spicka and Naglova, 2017) and to assess how policymakers can influence choice there is a need for greater understanding of the dynamics of price changes within the spectrum of income brackets. Thus, this paper examines the extent to which an understanding of price sensitivity can be used to influence dietary and food choices because the price is an important factor in food choice, especially for low-income consumers which are significantly more conscious of value and price than higher-income consumers (Steenhuis, Waterlander and de Mul, 2011). The quantification of price sensitivity and consumption saturation for different income levels between consumers and countries brings new information about consumer behaviour. This study focuses on meat as an essential part of the human diet in dietary concerns.

The article aims to calculate income elasticity and consumption saturation of major groups of meat and meat products in the Czech Republic and the United Kingdom in different income groups of consumers. The purpose of the article is to show different consumer behaviour between ten different income levels (deciles) and different countries. The literature review revealed interesting topics which are worth to be investigated. Thus, the article measures the elasticity distance between income deciles in the UK and the Czech Republic, countries with different level of income and consumer preferences.

The comparison with the United Kingdom should reveal differences between countries with different purchasing power and consumption patterns. The United Kingdom is considered as a high- income country (GDP per capita in PPS $=104 \%$ of the EU 27 in 2019, Eurostat) compared to the Czech Republic (GDP per capita in PPS $=92 \%$ of the EU 27 in 2019, Eurostat).

The results can help policymakers set some fiscal interventions to improve diets and food producers to forecast meat consumption in different customer segments. Alternatively, policymakers might consider regressive food taxes to make healthy foods for a low-income population more affordable. Producers and retailers can use income elasticity information in targeting promotional discounts (Kučerová and Zeman, 2013).

\section{Theoretical background}

The conceptual basis for the estimation of income and price elasticity is the neoclassical theory of consumer behaviour. Income elasticity of demand measures sensitivity of the quantity demand for a good or service to a $1 \%$ change in income, while other factors are constant (Benda Prokeinova and Hanova, 2016). It is similar to price elasticity of demand which "describes the percentage by which the demanded quantity of a food changes in response to a $1 \%$ increase in the price of the food" (Green et al., 2013). It is an important indicator of past and future consumers behaviour, and it is closely related to the income distribution of the population. The comparison between monetary and natural income elasticity also enables to reveal preferences of meat quality (Hálová, 2006). In this context, the key concern of this paper is the demand for meat and meat products.

This paper particularly compares consumption patterns and the influence of price on consumption patterns in the UK and the Czech Republic between 2000 and 2017. The question emerges as to whether the manipulation of prices through taxation can alter the nature of consumption and dietary choice.

It is possible to distinguish inferior, normal, necessity, luxury and superior goods through income elasticity. The case study from Slovakia indicated that dairy products, fruits and vegetables are perceived as luxuries. On the other hand, cereals, meat and fish and other food are normal goods with positive budget elasticity smaller than one and price inelastic demand (Cupák, Pokrivčák and Rizov, 2015; Hupková, Bielik and Turčeková, 2009).

There are differences in income elasticity between low-income customers and high-income customers (Smed et al., 2007). It is vital to stress Engel's law (Pearce, 1986), which assumes a falling proportion 
of income spent on food when income rises, even if absolute expenditure on food rises (less than proportionally). Engel curves vary by gender and householder education, the number of minor children and adults (Li, Song and $\mathrm{Ma}, 2015)$.

Much literature empirically estimates income or price elasticity of various goods in different regions (Clements and Si, 2016; Muhammad et al., 2017; Ren et al., 2018). They use various methods of elasticity estimation. Experimental studies are the widely used way how to estimate willingnessto-pay for goods and services. Their main advantage is that "the controlled nature of experimental settings can help to disentangle the effect of the pricing intervention from confounders" (Mizdrak et al., 2015). On the other hand, they "cannot be used in isolation to determine the effects of pricing interventions" (Mizdrak et al., 2015). Another study used sectional, cohort and quasi-experimental research methods, mostly used supermarket scanner surveys (Green et al., 2013).

An important finding from the systematic literature review is that demand for all food groups was more responsive to price changes in lower-income countries than higher-income countries (Green et al., 2013). Generally, all meat products' income elasticities tend to decline as per capita income increases (De Zhou et al., 2018). The income elasticity also depends on the importance of particular food category in the consumption. For example, pork meat's income elasticity, the most important meat consumed in China, declined faster with higher per capita income than the elasticity any other meat products (poultry, beef \& mutton).

It has implications for the Czech Republic, where people are quite sensitive to price changes and look for discounts. Green's literature review found the highest predicted price elasticities for meat in low-income countries he implication of the finding is twofold. First, the Czech government and food processors' efforts to promote Czech products, which are mostly more expensive than imported food, can harm low-income groups. Second, at the aggregate level, "increases in food prices are likely to have a disproportionately greater impact on food consumption in low-income countries" (Green et al., 2013).

Alternative results can be found when calculating income elasticity in the high-income country, like in Sweden (Lundberg and Lundberg, 2012), not between high- and low- income countries.
In the high-income countries, additional income does not result in higher calories intake (as in lowincome countries). Still, it may rather result in more aspirational spending towards diet diversification, improved quality, convenience, organic, fair trade, and animal welfare (Regmi and Meade, 2013). In the high-income country, the income elasticity is significantly higher for high-income households than in low-income households. Authors explain the effect by substitution of normal goods by exclusive goods when receiving an increase in income. This is an important difference from the low-income countries in Africa (Dubihlela, 2014). The difference in income elasticity between high- and low-income countries is also relevant for this study, which evaluates the differences between the United Kingdom (as a representant of the high-income country) and the Czech Republic (middle-income country) in Europe.

However, there are also significant differences in income elasticities across food and nutrient groups in low-income countries where people prefer basic diets, not exclusive food. Even in the low-income countries, the later research confirmed: "lower-income elasticities of basic foods compared to the less basic and more aspirational foods" (Colen et al., 2018). However, meat and fish consumption are no longer considered a luxury than in the past (Regmi and Meade, 2013).

Systematic literature review about price elasticity was conducted in the United States (Andreyeva, Long and Brownell, 2010). Authors found absolute value of mean price elasticity estimate at 0.75 for beef meat (0.67-0.83, 95\% confidence interval), 0.72 for pork meat $(0.66-0.78,95 \% \mathrm{CI})$ and 0.68 for poultry meat $(0.44-0.92,95 \% \mathrm{CI})$. The study points out the public health perspective. There is an area for investigation the cross-effects of price changes on substitutions from unhealthy to healthy food choices (e.g. from pork to poultry) or alternative substitutions.

Some empirical studies focus on the income elasticity of food in Central Europe and the UK. The income elasticity of meat and meat products' expenditures varied between 0.372 in the highest quartile to 0.725 in the lowest quartile in Slovakia. Moreover, low-income households have unmet nutritional needs due to their low purchasing power. The income elasticity of bread and bakery products did not vary so much between income quartiles (Kubicová et al., 2011). Later study calculated income elasticity of meat at 0.915 on average by a different method (Cupák et al., 2015). Another 
study focused on patterns, and preference changes in the consumer demand for meat in Slovakia showed that beef (2.162) and pork (1.027) were expenditure (income) elastic and hence could be considered as a luxury, while poultry (0.043) and fish $(-0.345)$ were income inelastic meaning that those were of necessity" (Benda Prokeinova and Hanova, 2016). In the Czech Republic, the income elasticity of meat and meat products was 0.8346 in the 1990s (Syrovátka, 2012), later study confirmed income elasticity of meat and meat products between 0.3 (pork meat) and 0.6 (beef) in the Czech Republic in 2004 (Hálová, 2006).

The study of food prices and household income in the UK confirmed lower-income elasticities for meat and fish than in Slovakia (De Agostini, 2014). The assumption is that the income elasticities of meat and meat products are higher in the Czech Republic than in the UK, indicating the relationships between food income elasticities in the EU study (Salotti et al., 2015). However, meat prices and income elasticities are more elastic than other food products such as dairy and eggs (Tiffin et al., 2011). Research in other countries such as Slovakia (Kubicová et al., 2011) a UK study suggests that price and income elasticity varies across socio-economic and demographic groups. Tiffin et al. (2011), based on findings within an earlier publication (Tiffin and Arnoult, 2010), find that price and income elasticities for meat for low-income families are lower than those of the total UK population. They conclude meat consumption in lower-income households in the UK are less affected by income changes than the national average (Tiffin et al., 2011). The literature also suggests that low incomes and children's presence may have a negative impact on dietary quality (Tiffin and Arnoult, 2010). Similar results have been determined by Green et al. (Green et al., 2013) in a systematic review of over 162 different countries' studies.

Studies about meat consumption in the UK have a strong focus on the effects of fiscal policy on a diet. The general conclusion is that "food taxes and subsidies have the potential to contribute to healthy consumption patterns at the population level" (Thow et al., 2010) but "the tax is insufficient to achieve this goal for fat intakes" (Tiffin and Arnoult, 2011). More impact evaluation is needed in developing countries.

The methodological problem related to the calculation of income elasticity is to select a suitable functional form. Different models are used for stationary elasticity estimation, changing elasticities over time and relationships between income and price elasticities. When estimating the right functional form of the income/price elasticity, locally flexible functional forms have proved popular in empirical applications - indirect translog model (Christensen, Jorgenson and Lau, 1975), generalised Leontief, Fourier flexible demand model (Gallant, 1981), all explained by (Wohlgenant, 1984), and almost ideal demand system (AIDS).

The cross-effects between food and other goods or between different food categories can be captured through almost ideal demand system AIDS, developed by (Deaton and Muellbauer, 1980) and applied recently in the linear form, e.g., by Aftab, Yaseen and Anwar (2017), quadratic form (Konig and Dovadova, 2016) and generalised form (Hovhannisyan and Gould, 2014). The AIDS system has been widely used in the priceand income elasticity estimation because its properties in relation to the consumers' preferences are well known (Ulubasoglu et al., 2015). However, "one drawback with this approach is the complexity of the demand system and the increasing number of parameters to be estimated as the number of equations and covariates increases" (Lundberg and Lundberg, 2012). An alternative approach is to estimate one single demand function where all other consumption determinants are regarded as the numerate goods, recently described by (Lundberg and Lundberg, 2012). The approach enables to include many potentially important determinants of food demand and expenditure.

Time series analysis, especially cointegration and error correction (ECM) analysis, was applied by Türkekul and Unakitan (2011). This approach is useful when data about prices, income and consumption in various income groups are available in a sufficiently long time series. Using time-series here makes sense statistically to control the correlation in elasticity between different time points (Engle and Granger, 1987). We will follow this approach in the article.

\section{Material and methods}

The official statistic services provided data in the Czech Republic (Czech Statistical Office, 2020) and the UK (Office for National Statistics, 2020) because they are not publicly available. The Czech Republic uses representative household budget surveys (HBS) in approximately 3000 
households (Czech Statistical Office, 2020). Selection of households for HBS had been made using a quota sampling technique till 2016. The quota frames used to be set following households' structure from EU-SILC Survey (national module of European Union - Statistics on Income and Living Conditions). The sampling and reporting unit of HBS was the private household whose members entered all expenses into diaries during the whole year. Diaries used to be structured according to international COICOP (Classification of Individual Consumption by Purpose) classification. Meat and meat products in the COICOP are classified in the following way; some items were joined because of data availability.

The Czech database was manually harmonised with Living costs and food survey (LCF). Like the HBS, data is collected for a sample of more than 5000 households across the United Kingdom using self-reported diaries (Office for National Statistics, 2020). The investigated product group - meat and meat products - includes the following groups of products.

- 01.1.2.2: Meat, fresh, chilled or frozen

- $\quad$ Beef $=$ Beef joints (on the bone); Beef joints (boned); Beefsteak (less expensive), Beefsteak (more expensive); Minced beef; All other beef and veal

。 $\quad$ Pork $=$ Pork joints; Pork chops; Pork fillets and steaks; All other pork

- $\quad$ Poultry = Chicken, uncooked (whole chicken or chicken pieces); Other poultry, uncooked (including frozen); Cooked poultry not purchased in cans

- 01.1.2.3: Meat, dried, salted, in brine or smoked

- Bacon and ham = cooked, uncooked

- 01.1.2.4: Offal, blood and other parts of slaughtered animals, fresh, chilled or frozen, dried, salted, in brine or smoked

- Other meat and offal $=$ Liver of all animals; Other fresh, chilled and frozen meat; Mutton and lamb

- 01.1.2.5: Meat, offal, blood and other parts of slaughtered animals' preparations

- Canned meat, other meat-based products = Sausages (uncooked); Meat pies and sausage rolls; ready to eat; Meat pies, pastries and puddings, frozen or not frozen; Burgers, frozen or not frozen; Ready meals and convenience meat products; Pate and delicatessen type sausage; Meat pastes and spreads; Takeaway meats; Corned beef, canned or sliced; Other cooked meat; Other canned meat and canned meat products

Fish and seafood are not included because of their marginality in the Czech Republic. Meat and meat products do not include public catering and eating in restaurants. If we include the food outside the home in foodservice operations etc., then consumption of meat has risen in the UK. This is because more and more consumption takes place outside the home. That's the main limitation of the study.

Data about net monetary income, net monetary expenditures and natural consumption of meat and meat products per capita are divided by income deciles. For example, the first $10 \%$ decile covers $10 \%$ of the households with the lowest income. We also calculated the unit price as the annual net monetary expenditure divided per capita by annual natural consumption. Deciles make the analysis more detailed than quintiles which have been usually published. Because monetary data from the Czech Republic and the UK are not comparable, they were converted to Euro through the Eurostat's official annual average exchange rate.

The time series starts in 2000 because of the strategic document Agenda 2000 that established pre-accession negotiations on EU enlargement (the Czech Republic joined the EU in 2004). Another reason is methodological. The Czech Statistical Office has used the COICOP classification since 1999/2000. The older data are not comparable. Due to major changes in methodology in the Czech Republic, the HBS time series was discontinued in 2016, but authors received an estimation by $\mathrm{Czech}$ Statistical Office for 2017. So, the time series covers 18 years (2000-2017).

To estimate the income elasticity of meat in the Czech Republic and the United Kingdom in different income groups of consumers, a cointegration analysis of time series was performed (Engle and Granger, 1987). We identified the cointegration analysis and separated the longterm relationships between the analyzed indicators from the short-term relationships using an error correction model (ECM).

Since our goal is to estimate elasticity and all analysed time series are non-stationary, 
a cointegration regression model in logarithmic expression in the form of

$$
\begin{aligned}
& \ln C O N_{t}=\beta_{0}+\beta_{1} \ln I N C_{t}+\varepsilon_{t} \text { or } \\
& \ln N M E_{t}=\beta_{0}+\beta_{1} \ln I N C_{t}+\varepsilon_{t},
\end{aligned}
$$

where $C O N$ is natural meat consumption ( $\mathrm{kg}$ per capita per year), NME is average net money expenditure (monetary consumption per capita per year) and $I N C$ is annual average net money income per capita, $\beta_{0}$ a $\beta_{1}$ ( $\beta_{1}$ expresses elasticity) are model parameters that we estimate through OLS and $\varepsilon_{t}$ is a non-systematic component of the model with white noise properties.

Regression models of non-stationary time series are often burdened by so-called spurious regression. To eliminate this problem, we performed an EngleGranger test of cointegration (Engle and Granger, 1987) using the ADF unit-root test (Dickey and Fuller, 1979). The last step of our analysis was to perform diagnostic tests on the estimated models, i.e. the Breusch-Godfrey test of autocorrelation (Breusch and Godfrey, 1986), the ARCH test of heteroscedasticity (Darnell, 1994) and the Jarque -Bera normality test (Jarque and Bera, 1980).

To estimate the saturation level, al of the second Törnquist function was calculated (Hálová, 2015). A basic economic assumption is that if a disposable income increases, the consumption of considered estate will increase and vice versa. However, this statement is true only up to a specific income limit. To obtain such an income limit, when the consumption grows no longer further, we speak about a level of saturation with the given estate. The consumer is unwilling to spend his/her income to purchase such an estate and orientates to other goods. The second Törnquist function can be expressed in the following way.

$y_{i}=a_{1} \frac{x_{p}-a_{3}}{a_{2}+x_{p}}$

Parameters $a_{1}$ and $a_{2}$ were estimated by iterative gradient optimisation method (MS Excel solver).

To reveal the demand for quality, the authors calculated the difference between monetary and natural income elasticities (monetary minus natural elasticities). The greater the difference between income elasticity in monetary and natural expression, the more the consumer chooses better quality goods and vice versa. The consumer is willing to provide much higher expenditure on higher-quality goods with approximately the same demand in kind.

\section{Results and discussion}

Table 1 shows the estimates of the dependence of natural consumption on income (first part) and the dependence of net monetary expenditures on income (second part) for the UK. Table 2 then contains the same estimates for the Czech Republic. The second and third columns of the tables contain parameter estimates and their significance level (the elasticity parameter is highlighted). $R^{2}{ }_{a d j}$ demonstrates the quality of the model. This is followed by a cointegration test (ADF test) and individual diagnostic tests on the estimated models. The last column, denoted by $\mathrm{D}$, represents the year for which it was necessary to introduce the dummy variable in the case of a structural breakpoint in the analysed time series.

At the 5\% significance level, the results show that the ADF test rejected the spurious regression in all models. Furthermore, the dependence of each pair of matching deciles of individual indicators was demonstrated in all models (statistically insignificant intercepts were left in the models for their comparability). Diagnostic tests show that the non-systematic component of the models is not autocorrelated, homoskedastic and has a normal distribution, i.e. it has white noise characteristics in all models.

Income is an important driving force that motivates people to change their consumption patterns. In the Czech Republic, the income elasticity in terms of natural consumption and net monetary expenditures is higher in first-decile households than in top-decile households. There are two possible reasons. Meat is a relatively expensive commodity, and wealthier consumers start to value health and environmental concerns (Vranken et al., 2014). Inter-deciles differences have no apparent trend in the UK. It confirms the empirical results that there is no clear relation between meat consumption and income. Still, there is a set of high-income countries where meat consumption is relatively low (Mathijs, 2015). Instead of the linear relationship between income and meat consumption, the authors suggested a non-linear, U-shaped relationship between meat consumption and income. "Initially, meat consumption increases with income, but from a certain point onwards higher levels of income lead to lower levels of meat consumption" (Mathijs, 2015; Vranken et al., 2014).

The income elasticity coefficient can be interpreted as a 1 per cent increase in the income is associated with a certain percentage decrease in quantity 


\begin{tabular}{|c|c|c|c|c|c|c|c|c|c|c|c|c|c|c|}
\hline \multirow{2}{*}{ dec. } & \multicolumn{2}{|c|}{$\hat{\beta}_{0}$} & \multicolumn{2}{|c|}{$\hat{\beta}_{1}$} & \multirow{2}{*}{$\mathrm{R}_{\text {adj }}^{2}$} & \multicolumn{2}{|c|}{$\mathrm{ADF}$} & \multicolumn{2}{|c|}{ Breusch-Godfrey } & \multicolumn{2}{|c|}{$\mathrm{ARCH}$} & \multicolumn{2}{|c|}{ Jarque-Bera } & \multirow{2}{*}{ D } \\
\hline & $\mathrm{t}$ & $\mathrm{p}$-value & $\mathrm{t}$ & $\mathrm{p}$-value & & $\mathrm{t}$ & $\mathrm{p}$-value & $\mathrm{F}$ & p-value & $\mathrm{F}$ & p-value & JB & $\mathrm{p}$-value & \\
\hline \multicolumn{15}{|c|}{ consumption of meat } \\
\hline 10 & 5.721 & 0.000 & -0.209 & 0.018 & 0.275 & -3.112 & 0.004 & 0.915 & 0.425 & 1.580 & 0.229 & 0.262 & 0.877 & \\
\hline 20 & 8.429 & 0.000 & -0.476 & 0.000 & 0.638 & -3.017 & 0.005 & 0.616 & 0.555 & 0.852 & 0.372 & 0.693 & 0.707 & \\
\hline 30 & 6.414 & 0.000 & -0.255 & 0.008 & 0.342 & -2.721 & 0.010 & 0.638 & 0.544 & 0.030 & 0.864 & 0.591 & 0.744 & \\
\hline 40 & 6.584 & 0.000 & -0.269 & 0.019 & 0.512 & -2.430 & 0.019 & 1.691 & 0.222 & 0.058 & 0.814 & 4.307 & 0.116 & 2009 \\
\hline 50 & 7.350 & 0.000 & -0.340 & 0.001 & 0.473 & -4.004 & 0.001 & 1.810 & 0.203 & 0.007 & 0.934 & 0.009 & 0.995 & \\
\hline 60 & 6.466 & 0.000 & -0.246 & 0.000 & 0.564 & -4.724 & 0.000 & 0.262 & 0.774 & 0.007 & 0.934 & 1.023 & 0.600 & \\
\hline 70 & 7.896 & 0.000 & -0.381 & 0.001 & 0.509 & -3.908 & 0.001 & 0.064 & 0.939 & 0.048 & 0.830 & 0.481 & 0.786 & \\
\hline 80 & 7.372 & 0.000 & -0.324 & 0.000 & 0.560 & -4.074 & 0.001 & 0.526 & 0.603 & 1.249 & 0.283 & 0.423 & 0.809 & \\
\hline 90 & 6.289 & 0.000 & -0.217 & 0.012 & 0.555 & -4.728 & 0.000 & 0.655 & 0.537 & 0.131 & 0.722 & 0.201 & 0.905 & $\begin{array}{r}2005 \\
2008\end{array}$ \\
\hline 100 & 7.311 & 0.000 & -0.301 & 0.008 & 0.343 & -3.069 & 0.005 & 1.184 & 0.337 & 0.471 & 0.504 & 3.142 & 0.208 & \\
\hline \multicolumn{15}{|c|}{ net money expenditures } \\
\hline 10 & -0.841 & 0.441 & 0.694 & 0.000 & 0.674 & -2.734 & 0.010 & 1.306 & 0.304 & 0.516 & 0.484 & 1.333 & 0.513 & \\
\hline 20 & 1.438 & 0.058 & 0.429 & 0.000 & 0.671 & -3.106 & 0.004 & 1.008 & 0.392 & 0.140 & 0.714 & 0.245 & 0.885 & \\
\hline 30 & -2.413 & 0.002 & 0.822 & 0.000 & 0.919 & -3.381 & 0.003 & 0.413 & 0.671 & 0.845 & 0.373 & 0.527 & 0.768 & 2000 \\
\hline 40 & -3.336 & 0.004 & 0.904 & 0.000 & 0.838 & -3.137 & 0.004 & 0.235 & 0.794 & 0.293 & 0.597 & 0.565 & 0.754 & \\
\hline 50 & -3.351 & 0.036 & 0.896 & 0.000 & 0.697 & -2.654 & 0.012 & 1.102 & 0.361 & 0.065 & 0.803 & 0.753 & 0.686 & \\
\hline 60 & -3.543 & 0.006 & 0.907 & 0.000 & 0.809 & -2.054 & 0.042 & 3.210 & 0.074 & 0.652 & 0.433 & 0.553 & 0.758 & \\
\hline 70 & -2.476 & 0.051 & 0.794 & 0.000 & 0.751 & -2.264 & 0.027 & 1.719 & 0.218 & 0.148 & 0.706 & 0.379 & 0.827 & \\
\hline 80 & -2.131 & 0.068 & 0.753 & 0.000 & 0.763 & -2.776 & 0.010 & 1.048 & 0.378 & 0.481 & 0.499 & 2.785 & 0.248 & \\
\hline 90 & -3.620 & 0.001 & 0.884 & 0.000 & 0.877 & -3.413 & 0.002 & 0.483 & 0.627 & 0.989 & 0.337 & 0.263 & 0.877 & \\
\hline 100 & -2.433 & 0.134 & 0.741 & 0.000 & 0.638 & -3.222 & 0.003 & 0.231 & 0.797 & 1.245 & 0.283 & 0.931 & 0.628 & \\
\hline
\end{tabular}

Source: own calculations

Table 1: Income elasticity coefficients of meat consumption in the UK.

\begin{tabular}{|c|c|c|c|c|c|c|c|c|c|c|c|c|c|c|}
\hline \multirow{2}{*}{ dec. } & \multicolumn{2}{|c|}{$\hat{\beta}_{0}$} & \multicolumn{2}{|c|}{$\hat{\beta}_{1}$} & \multirow{2}{*}{$\mathrm{R}_{\mathrm{adj}}^{2}$} & \multicolumn{2}{|c|}{$\mathrm{ADF}$} & \multicolumn{2}{|c|}{ Breusch-Godfrey } & \multicolumn{2}{|c|}{$\mathrm{ARCH}$} & \multicolumn{2}{|c|}{ Jarque-Bera } & \multirow{2}{*}{ D } \\
\hline & $t$ & p-value & $t$ & $\mathrm{p}$-value & & $\mathrm{t}$ & p-value & $\mathrm{F}$ & p-value & $\mathrm{F}$ & p-value & JB & $\mathrm{p}$-value & \\
\hline \multicolumn{15}{|c|}{ consumption of meat } \\
\hline 10 & -1.768 & 0.025 & 0.494 & 0.000 & 0.784 & -2.221 & 0.030 & 2.517 & 0.119 & 0.241 & 0.631 & 0.109 & 0.947 & \\
\hline 20 & 0.829 & 0.123 & 0.264 & 0.000 & 0.748 & -3.350 & 0.002 & 1.397 & 0.285 & 0.225 & 0.642 & 0.813 & 0.666 & 2008 \\
\hline 30 & -0.050 & 0.934 & 0.354 & 0.000 & 0.742 & -4.393 & 0.000 & 0.983 & 0.400 & 0.238 & 0.633 & 1.321 & 0.517 & \\
\hline 40 & 0.644 & 0.251 & 0.297 & 0.000 & 0.708 & -2.474 & 0.017 & 1.601 & 0.242 & 1.851 & 0.195 & 1.089 & 0.580 & 2016 \\
\hline 50 & 0.225 & 0.762 & 0.334 & 0.000 & 0.632 & -2.377 & 0.021 & 1.373 & 0.288 & 0.040 & 0.844 & 0.800 & 0.670 & \\
\hline 60 & 1.268 & 0.058 & 0.244 & 0.000 & 0.561 & -2.598 & 0.013 & 0.699 & 0.515 & 0.020 & 0.891 & 0.523 & 0.770 & \\
\hline 70 & -0.491 & 0.322 & 0.390 & 0.000 & 0.851 & -5.432 & 0.000 & 0.717 & 0.506 & 1.635 & 0.222 & 0.050 & 0.975 & \\
\hline 80 & 0.257 & 0.713 & 0.329 & 0.000 & 0.665 & -3.148 & 0.004 & 0.261 & 0.775 & 1.868 & 0.193 & 0.164 & 0.921 & \\
\hline 90 & 1.395 & 0.055 & 0.233 & 0.001 & 0.511 & -3.737 & 0.001 & 0.014 & 0.986 & 0.475 & 0.502 & 0.235 & 0.889 & \\
\hline 100 & 1.897 & 0.000 & 0.188 & 0.000 & 0.681 & -2.787 & 0.009 & 0.543 & 0.594 & 0.420 & 0.527 & 2.024 & 0.363 & \\
\hline \multicolumn{15}{|c|}{ net money expenditures } \\
\hline 10 & -2.092 & 0.001 & 0.925 & 0.000 & 0.961 & -3.052 & 0.005 & 1.148 & 0.347 & 0.096 & 0.762 & 0.669 & 0.716 & \\
\hline 20 & 0.657 & 0.280 & 0.675 & 0.000 & 0.914 & -5.339 & 0.000 & 0.001 & 0.999 & 2.480 & 0.138 & 0.727 & 0.695 & \\
\hline 30 & 0.522 & 0.451 & 0.693 & 0.000 & 0.897 & -2.333 & 0.024 & 0.672 & 0.528 & 1.502 & 0.241 & 0.443 & 0.801 & \\
\hline 40 & 1.646 & 0.003 & 0.597 & 0.000 & 0.930 & -2.595 & 0.014 & 2.151 & 0.156 & 0.151 & 0.703 & 0.102 & 0.950 & \\
\hline 50 & 0.891 & 0.205 & 0.662 & 0.000 & 0.891 & -3.119 & 0.004 & 0.812 & 0.465 & 1.971 & 0.182 & 0.173 & 0.917 & \\
\hline 60 & 1.733 & 0.002 & 0.589 & 0.000 & 0.937 & -2.763 & 0.010 & 1.165 & 0.343 & 0.308 & 0.588 & 0.538 & 0.764 & \\
\hline 70 & 0.657 & 0.351 & 0.675 & 0.000 & 0.895 & -2.773 & 0.009 & 0.931 & 0.419 & 0.392 & 0.541 & 1.215 & 0.545 & \\
\hline 80 & 0.857 & 0.252 & 0.656 & 0.000 & 0.881 & -2.714 & 0.010 & 1.645 & 0.231 & 0.119 & 0.735 & 0.571 & 0.751 & \\
\hline 90 & 1.571 & 0.022 & 0.593 & 0.000 & 0.895 & -3.127 & 0.004 & 1.116 & 0.357 & 0.123 & 0.731 & 1.431 & 0.489 & \\
\hline 100 & 2.343 & 0.000 & 0.517 & 0.000 & 0.909 & -2.603 & 0.013 & 2.344 & 0.138 & 0.256 & 0.621 & 0.715 & 0.699 & $\begin{array}{l}2001, \\
2013\end{array}$ \\
\hline
\end{tabular}

Source: own calculations

Table 2: Income elasticity coefficients of meat consumption in the Czech Republic 
demanded (sales), on average. For example, when considering the first income decile and natural meat consumption in the Czech Republic, the elasticity is 0.494 . So, a 1 per cent increase in the income is associated with a 0.494 per cent increase in quantity demanded. The elasticity calculated from the net money expenditures is always higher than elasticity based on natural consumption because of price-related effects.

At first glance, there is a big difference in the income elasticity of natural consumption between the two countries. The income elasticity of meat is positive in the Czech Republic ranging between 0.188 and 0.494 ; the UK has negative income elasticity from -0.476 to -0.209 . However, the income elasticity of net money expenditures is positive in both countries. The chief cause of the discrepancy between income elasticity of natural consumption and net monetary expenditures is the UK's unit price (Figure 1).
Figure 1 clearly shows the higher price growth of meat in the UK than in the Czech Republic in all income deciles. However, the UK's meat consumption declines in the long term in all income deciles, as Figure 2 presents. The more detailed statistics revealed that the decline of red meat consumption was more dynamic than poultry meat consumption in most income deciles in the UK. Alternatively, there is a positive relationship between income development and meat consumption in the Czech Republic. Thus, the results indicate completely different dietary trends between the two countries. Increasing evidence suggests that a final shift occurs, following behavioural change towards consuming higher-quality fats, more whole grains, fruit and vegetables, and particularly less meat in high-income and developed countries, such as the UK (Mathijs, 2015). This process is called nutrition transitions (Popkin, 2006). There are various factors which can cause a downward trend

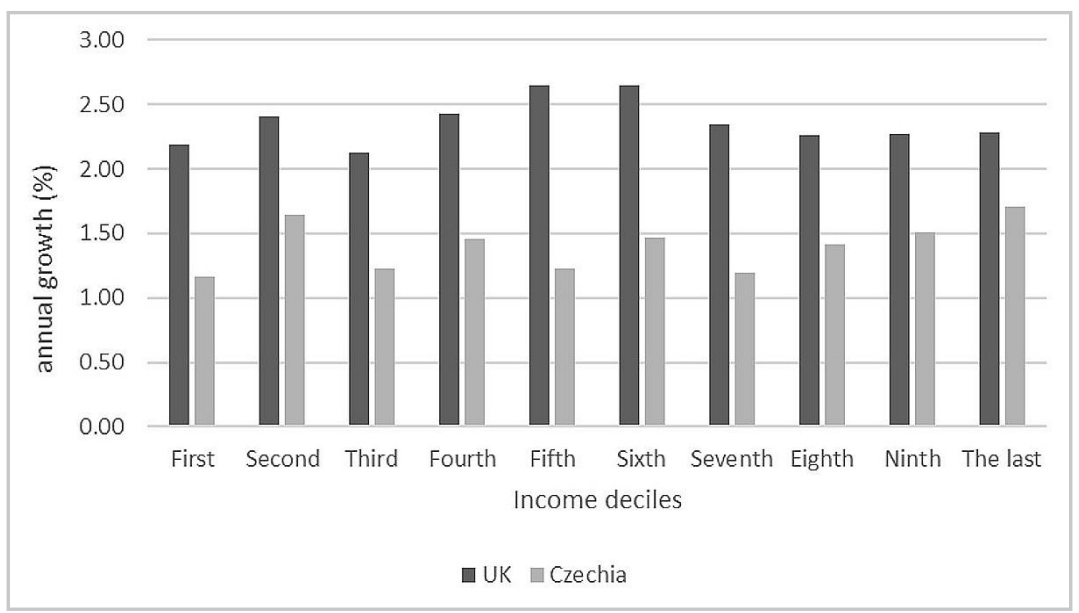

Source: authors

Figure 1: Average annual growth of per-unit meat prices (\%).

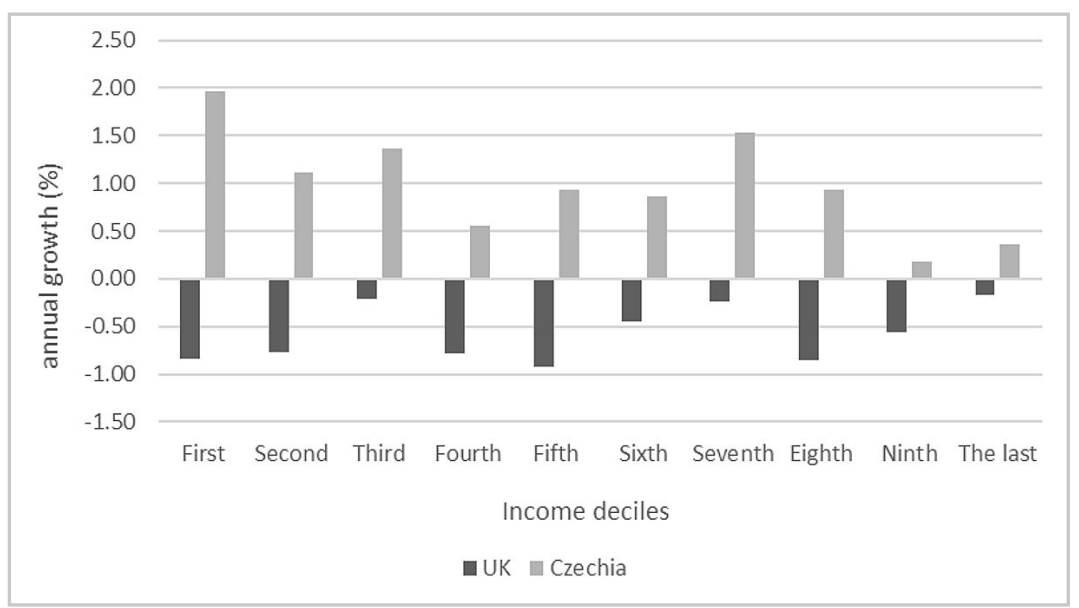

Source: authors

Figure 2: Average annual growth of natural meat consumption (\%). 
in meat consumption in high-income countries.

The possible explanation of different consumption trends in the Czech Republic and the UK can be found in saturation level and different demand for quality. Tables 3 a 4 present differences between monetary and natural income elasticities in both countries.

The differences are similar in the lower-income deciles in both countries but significantly differ in higher-income deciles between the Czech Republic and the UK. The critical finding is that consumers with above-average income in the UK prefer quality much more than the same groups in the Czech Republic. Nevertheless, the demand for quality has increased in all income groups in the Czech Republic and lower-income groups in the UK. Alternatively, the higher-income groups in the UK have not increased the demand for quality in the long period since they are nearly saturated (Table 5).

In the UK, the saturation limit is lower than in the Czech Republic, and consumers focus

\begin{tabular}{|c|c|c|c|c|c|c|c|c|c|c|c|c|c|c|c|c|c|c|c|}
\hline $\mathrm{CZ}$ & 2000 & 2001 & 2002 & 2003 & 2004 & 2005 & 2006 & 2007 & 2008 & 2009 & 2010 & 2011 & 2012 & 2013 & 2014 & 2015 & 2016 & 2017 & $\begin{array}{l}\text { Trend } \\
\text { (geo- } \\
\text { mean) }\end{array}$ \\
\hline $\begin{array}{l}\text { First } \\
10 \%\end{array}$ & 0.052 & 0.060 & 0.063 & 0.061 & 0.068 & 0.074 & 0.060 & 0.063 & 0.067 & 0.062 & 0.050 & 0.049 & 0.050 & 0.047 & 0.050 & 0.056 & 0.063 & 0.073 & 102.0 \\
\hline $\begin{array}{c}\text { Second } \\
10 \%\end{array}$ & 0.057 & 0.066 & 0.070 & 0.067 & 0.076 & 0.083 & 0.069 & 0.075 & 0.079 & 0.075 & 0.059 & 0.060 & 0.062 & 0.058 & 0.060 & 0.068 & 0.076 & 0.090 & 102.7 \\
\hline $\begin{array}{l}\text { Third } \\
10 \%\end{array}$ & 0.059 & 0.069 & 0.073 & 0.071 & 0.079 & 0.087 & 0.073 & 0.080 & 0.084 & 0.081 & 0.063 & 0.065 & 0.066 & 0.062 & 0.064 & 0.073 & 0.080 & 0.097 & 102.9 \\
\hline $\begin{array}{c}\text { Fourth } \\
10 \%\end{array}$ & 0.061 & 0.070 & 0.074 & 0.072 & 0.081 & 0.089 & 0.076 & 0.084 & 0.088 & 0.085 & 0.066 & 0.067 & 0.069 & 0.065 & 0.066 & 0.076 & 0.083 & 0.100 & 103.0 \\
\hline $\begin{array}{l}\text { Fifth } \\
10 \%\end{array}$ & 0.062 & 0.072 & 0.076 & 0.074 & 0.083 & 0.091 & 0.078 & 0.087 & 0.091 & 0.089 & 0.068 & 0.070 & 0.071 & 0.067 & 0.068 & 0.079 & 0.085 & 0.104 & 103.1 \\
\hline $\begin{array}{l}\text { Sixth } \\
10 \%\end{array}$ & 0.063 & 0.073 & 0.077 & 0.075 & 0.085 & 0.093 & 0.081 & 0.089 & 0.094 & 0.093 & 0.070 & 0.072 & 0.073 & 0.069 & 0.069 & 0.081 & 0.088 & 0.109 & 103.3 \\
\hline $\begin{array}{c}\text { Seventh } \\
10 \%\end{array}$ & 0.064 & 0.074 & 0.079 & 0.077 & 0.086 & 0.096 & 0.084 & 0.093 & 0.098 & 0.098 & 0.072 & 0.076 & 0.075 & 0.072 & 0.071 & 0.084 & 0.090 & 0.114 & 103.5 \\
\hline $\begin{array}{c}\text { Eighth } \\
10 \%\end{array}$ & 0.065 & 0.075 & 0.080 & 0.078 & 0.088 & 0.098 & 0.087 & 0.097 & 0.103 & 0.105 & 0.076 & 0.080 & 0.078 & 0.075 & 0.073 & 0.088 & 0.094 & 0.120 & 103.7 \\
\hline $\begin{array}{l}\text { Ninth } \\
10 \%\end{array}$ & 0.065 & 0.076 & 0.081 & 0.080 & 0.090 & 0.101 & 0.091 & 0.101 & 0.107 & 0.112 & 0.079 & 0.084 & 0.080 & 0.079 & 0.076 & 0.092 & 0.097 & 0.128 & 104.0 \\
\hline $\begin{array}{c}\text { The last } \\
10 \%\end{array}$ & 0.063 & 0.074 & 0.080 & 0.079 & 0.089 & 0.101 & 0.094 & 0.106 & 0.113 & 0.124 & 0.082 & 0.091 & 0.083 & 0.084 & 0.077 & 0.097 & 0.099 & 0.138 & 104.7 \\
\hline
\end{tabular}

Source: own calculation

Table 3: Differences between monetary and natural income elasticities in the Czech Republic.

\begin{tabular}{|c|c|c|c|c|c|c|c|c|c|c|c|c|c|c|c|c|c|c|c|}
\hline UK & 2000 & 2001 & 2002 & 2003 & 2004 & 2005 & 2006 & 2007 & 2008 & 2009 & 2010 & 2011 & 2012 & 2013 & 2014 & 2015 & 2016 & 2017 & $\begin{array}{l}\text { Trend } \\
\text { (geo- } \\
\text { mean) }\end{array}$ \\
\hline $\begin{array}{l}\text { First } \\
10 \%\end{array}$ & 0.036 & 0.053 & 0.052 & 0.069 & 0.047 & 0.078 & 0.065 & 0.054 & 0.060 & 0.055 & 0.046 & 0.051 & 0.060 & 0.057 & 0.062 & 0.057 & 0.063 & 0.062 & 103.2 \\
\hline $\begin{array}{c}\text { Second } \\
10 \%\end{array}$ & 0.062 & 0.083 & 0.086 & 0.108 & 0.077 & 0.118 & 0.104 & 0.086 & 0.099 & 0.087 & 0.077 & 0.080 & 0.093 & 0.093 & 0.103 & 0.097 & 0.105 & 0.103 & 103.1 \\
\hline $\begin{array}{l}\text { Third } \\
10 \%\end{array}$ & 0.082 & 0.103 & 0.109 & 0.132 & 0.094 & 0.141 & 0.127 & 0.106 & 0.124 & 0.106 & 0.096 & 0.097 & 0.109 & 0.112 & 0.124 & 0.111 & 0.119 & 0.117 & 102.1 \\
\hline $\begin{array}{c}\text { Fourth } \\
10 \%\end{array}$ & 0.103 & 0.123 & 0.128 & 0.154 & 0.111 & 0.162 & 0.146 & 0.125 & 0.145 & 0.123 & 0.112 & 0.113 & 0.127 & 0.128 & 0.142 & 0.127 & 0.136 & 0.134 & 101.6 \\
\hline $\begin{array}{l}\text { Fifth } \\
10 \%\end{array}$ & 0.122 & 0.141 & 0.145 & 0.175 & 0.126 & 0.180 & 0.165 & 0.142 & 0.164 & 0.140 & 0.127 & 0.129 & 0.144 & 0.143 & 0.158 & 0.143 & 0.142 & 0.150 & 101.2 \\
\hline $\begin{array}{l}\text { Sixth } \\
10 \%\end{array}$ & 0.144 & 0.162 & 0.163 & 0.195 & 0.141 & 0.199 & 0.184 & 0.161 & 0.183 & 0.157 & 0.144 & 0.147 & 0.162 & 0.161 & 0.177 & 0.161 & 0.168 & 0.168 & 100.9 \\
\hline $\begin{array}{c}\text { Seventh } \\
10 \%\end{array}$ & 0.167 & 0.183 & 0.183 & 0.218 & 0.159 & 0.220 & 0.204 & 0.181 & 0.204 & 0.176 & 0.164 & 0.167 & 0.181 & 0.180 & 0.197 & 0.181 & 0.181 & 0.188 & 100.7 \\
\hline $\begin{array}{c}\text { Eighth } \\
10 \%\end{array}$ & 0.200 & 0.208 & 0.205 & 0.242 & 0.180 & 0.243 & 0.228 & 0.206 & 0.233 & 0.198 & 0.189 & 0.190 & 0.203 & 0.201 & 0.220 & 0.206 & 0.212 & 0.212 & 100.3 \\
\hline $\begin{array}{l}\text { Ninth } \\
10 \%\end{array}$ & 0.252 & 0.246 & 0.236 & 0.276 & 0.211 & 0.278 & 0.263 & 0.239 & 0.272 & 0.230 & 0.224 & 0.224 & 0.235 & 0.233 & 0.251 & 0.237 & 0.239 & 0.243 & 99.8 \\
\hline $\begin{array}{c}\text { The last } \\
10 \%\end{array}$ & 0.492 & 0.363 & 0.337 & 0.364 & 0.319 & 0.369 & 0.355 & 0.348 & 0.376 & 0.318 & 0.328 & 0.338 & 0.329 & 0.318 & 0.325 & 0.329 & 0.323 & 0.335 & 97.8 \\
\hline
\end{tabular}

Source: own calculation

Table 4: Differences between monetary and natural income elasticities in the UK. 


\begin{tabular}{|l|c|c|c|c|}
\hline \multirow{2}{*}{} & \multicolumn{2}{|c|}{ Monetary (USD/cap) } & \multicolumn{2}{c|}{ Natural (kg/cap) } \\
\cline { 2 - 5 } & $\mathbf{C Z}$ & $\mathbf{U K}$ & $\mathbf{C Z}$ & UK \\
\hline Saturation limit & 628.4 & 494.4 & 86.8 & 54.2 \\
\hline \multicolumn{5}{|c|}{ The share of consumption to the saturation limit } \\
\hline First 10\% & $40.3 \%$ & $62.2 \%$ & $46.4 \%$ & $87.8 \%$ \\
\hline Second 10\% & $48.4 \%$ & $71.9 \%$ & $53.5 \%$ & $94.3 \%$ \\
\hline Third 10\% & $57.0 \%$ & $75.2 \%$ & $64.0 \%$ & $96.3 \%$ \\
\hline Fourth 10\% & $60.8 \%$ & $75.3 \%$ & $67.4 \%$ & $95.9 \%$ \\
\hline Fifth 10\% & $63.4 \%$ & $78.2 \%$ & $70.8 \%$ & $96.2 \%$ \\
\hline Sixth 10\% & $65.6 \%$ & $81.6 \%$ & $71.4 \%$ & $97.9 \%$ \\
\hline Seventh 10\% & $66.5 \%$ & $85.9 \%$ & $71.3 \%$ & $98.3 \%$ \\
\hline Eighth 10\% & $70.4 \%$ & $88.8 \%$ & $75.6 \%$ & $98.7 \%$ \\
\hline Ninth $10 \%$ & $75.0 \%$ & $94.6 \%$ & $78.2 \%$ & $98.7 \%$ \\
\hline The last 10\% & $78.8 \%$ & $100.0 \%$ & $80.2 \%$ & $93.9 \%$ \\
\hline
\end{tabular}

Source: own calculation

Table 5: Saturation limit and the share of consumption to saturation limit (\%) in monetary and natural expression (average of 2000-2017).

on other goods and services. In the Czech Republic, there is a potential to increase monetary and natural expression consumption, not in the UK where the saturation level was nearly reached.

Firstly, there are the impacts culture and tradition on preferred food choice and the choice of meats between the UK and the Czech Republic. The UK consumers prefer beef, poultry, fish and tinned meat while the most favourite meat of Czech consumers is pork and poultry meat. The Czech Republic is landlocked and does not have access to fresh seafood.

A second factor can be identified from recent studies, which have shown that the mortality rate could be affected by high intake of both red and processed meat whilst there are no or only moderate inverse associations observed for poultry (Etemadi et al., 2017; Wang et al., 2016). However, the results may be biased as high meat intakes may be associated with other major risk factors such as smoking, alcohol consumption and obesity. The most substantial evidence was found in association with colorectal cancer. Red meat is classified as probably carcinogenic to humans (Bouvard et al., 2015). Processed meat consumption also seems to be associated with risk for cardiovascular disease (Rohrmann et al., 2013) and chronic diseases such as diabetes and obesity (Wolk, 2017).

Additionally, meat consumption is associated with the level of income and wellbeing. "In highincome Western countries, a lower meat intake may be a marker of a health-conscious lifestyle, but in low-income countries, lower meat intakes are more likely to be markers of poverty and associated with other risk factors for poor health" (Godfray et al., 2018). Moreover, people in low-come countries often have limited access to alternative nutrient-dense foods.

The economic impacts of red meat consumption are closely associated with nutritional and environmental issues. The consumption of different types of meat and meat products has significant effects on people's health, and livestock production can negatively affect the environment. Thus, the taxation of unhealthy food is a topical issue in developed countries. Attempts to change diets through fiscal interventions also lies within a rational choice framework. For example, a coalition of the UK's health professions has called for a climate tax imposed on food with a heavy environmental impact by 2025, unless the industry takes voluntary action on the impact of their products. Denmark operated a tax on the 496 saturated fat content of foods between 2011 and 2012 , raising prices of some meat products by $15 \%$ (Godfray et al., 2018). A recent study estimated that "under optimal taxation, prices for processed meat increased by $25 \%$ on average, ranging from $1 \%$ in low-income countries to over $100 \%$ in high-income countries, and prices for red meat increased by $4 \%$, ranging from $0.2 \%$ to over $20 \%$. Consumption of processed meat decreased by $16 \%$ on average, ranging from $1 \%$ to $25 \%$, whilst red meat consumption remained stable 
as a substitution for processed meat compensated price-related reductions" (Springmann et al., 2018). Optimal taxation will also reduce the number of deaths attributable to red and processed meat consumption and save health costs globally (Springmann et al., 2018). Another study, however, concluded that meat consumption is difficult to influence through direct policy intervention. “Acting indirectly on consumers' preferences and consumption habits (for instance through information, education policy and increased availability of ready-made plant-based products) could be of key importance for mitigating the rise of meat consumption per capita all over the world" (Milford et al., 2019).

People in high-income countries have become more concerned about the impact of meat production on the environment. The FAO study provided evidence that meat produces more emissions per unit of energy than plant-based agriculture (Gerber et al., 2013). Ruminant production produces more emissions than that of nonruminant mammals and poultry. In contrast, intensive rearing tends to produce fewer GHG emissions than more extensive systems per unit of output despite having other environmental disadvantages (Godfray et al., 2018). Livestock production is also associated with water consumption. The study on livestock production's water footprint showed that beef farming is more water demanding than chicken production per kilogram of meat (Mekonnen and Hoekstra, 2012). Alternatively, replacing cropland with permanent pasture is one practice promoted for its potential to sequester soil carbon, i. e. particularly in hill farming or farming on marginal land. There is an argument that continued permanent pasture even where there are ruminants present a carbon zero scenario. Overall, public interventions in the form of nutrient tax to reduce red meat consumption would positively impact greenhouse gas emissions (Farchi et al., 2017; Harding and Lovenheim, 2017).

Finally, there is a growing concern within the younger generation concerning husbandry practices and animal welfare. Positive attitudes towards animal welfare are associated with consuming less meat and greater 'higher welfare' meat purchases (Clonan et al., 2015). There is an increasing trend of veganism, vegetarianism, and flexitarians. The research on the association of animal health concerns with diet choice provided evidence that contrast between flexitarians and vegetarians is greater than the contrast between flexitarians and full-time meat-eaters (De Backer and Hudders, 2015).

\section{Conclusion}

The article's purpose was to point out the difference in consumer behaviour between ten different income levels (deciles) across two countries: the Czech Republic and the UK. The two countries have different consumer preferences and income level. Meat consumption has been widely discussed because of environmental and health impacts, especially in the case of red meat.

The most influential finding is a big difference in the income elasticity of natural consumption between the two countries. The income elasticity of meat consumption is positive in the Czech Republic, while the UK has negative income elasticity. In other words, the natural consumption of meat increased with incomes grew in the Czech Republic. In contrast, there appears to be a diametric relationship between meat and income had in the UK. Nonetheless, the income elasticity of net money expenditures is positive in both countries. The chief cause of the discrepancy between income elasticity of natural consumption and net monetary expenditures is the higher unit price found in the UK. There was a higher price increase in the UK than in the Czech Republic in all income deciles.

The meat consumption patterns differ between the Czech Republic and the UK. Britons prefer beef, veal and sheep meat while pork meat is much more popular in the Czech Republic. Moreover, the UK's meat consumption is nearly saturated, and consumers in higher-income deciles are looking for high-quality meat much more than the same groups in the Czech Republic. The demand for quality has been increasing in all income groups in the Czech Republic and lower-income groups in the UK, which is an important signal for meat processors.

The results provide evidence that consumers in the UK are close to consumption saturation prefer high-quality meat which could have positive nutritional effects. Moreover, high-income countries discuss taxation of unhealthy food, which could lead to significant health and environmental benefits, particularly in high and middle-income countries, as recent studies found it.

In the Czech Republic, the income elasticity in terms of natural consumption and net monetary 
expenditures is higher in first-decile households than in top-decile households. The Czech case explains the popularity of discount campaigns in low-income households, especially households of seniors. On the contrary, the inter-deciles differences have no evident trend in the UK, which indicates the overall downward trend of household meat consumption. The article indicates completely different trends of human diet between the two countries. It supports the theory of nutrition transitions when the UK as a high income country is gradually changing consumer behaviour toward a healthy, high-quality and balanced diet.

The article's main limitation is that it doesn't include the food outside the home in food service operations. Then the consumption of meat has risen in the UK. This is because more and more consumption takes place outside the home. Further research could follow this trend.

\section{Acknowledgements}

Supported by the Ministry of Education, Youth and Sports of the Czech Republic, institutional support for the long-term development of research at the Prague University of Economics and Business, Faculty of Business Administration (IP 300040) and Faculty of Finance and Accounting (IP 100040).

\section{Corresponding authors}

prof. Ing. Jindřich Špička, Ph.D.

Faculty of Business Administration, Prague University of Economics and Business

W. Churchill Sq. 4, 13067 Prague, Czech Republic

E-mail: jindrich.spicka@vse.cz

\section{References}

[1] Aftab, S., Yaseen, M. R. and Anwar, S. (2017) "Impact of rising food prices on consumer welfare in the most populous countries of South Asia", International Journal of Social Economics, Vol. 44, No. 8, pp. 1062-1077. ISSN 0306-8293. DOI 10.1108/IJSE-01-2016-0016.

[2] Andreyeva, T., Long, M. W. and Brownell, K. D. (2010) "The impact of food prices on consumption: A systematic review of research on the price elasticity of demand for food", American Journal of Public Health, Vol. 100, No. 2, pp. 216-222. ISSN 0090-0036. DOI 10.2105/AJPH.2008.151415.

[3] Benda Prokeinova, R. and Hanova, M. (2016) "Modelling consumer's behaviour of the meat consumption in Slovakia", Agricultural Economics - Czech, Vol. 62, No. 5, pp. 235-245. ISSN 0139-570X. DOI 10.17221/33/2015-AGRICECON.

[4] Blazkova, I. (2016) "Convergence of Market Concentration: Evidence from Czech Food Processing Sectors", AGRIS on-line Papers in Economics and Informatics, Vol. 8, No. 4, pp. 25-36. ISSN 1804-1930. DOI 10.7160/aol.2016.080403.

[5] Bouvard, V., Loomis, D., Guyton, K. Z., Grosse, Y., Ghissassi, F. El, Benbrahim-Tallaa, L., Straif, K. (2015) "Carcinogenicity of consumption of red and processed meat", The Lancet Oncology, Vol. 16, No. 16, pp. 1599-1600. ISSN 1407-2045. DOI 10.1016/S1470-2045(15)00444-1.

[6] Breusch, T. S. and Godfrey, L. G. (1986) "Data Transformation Tests", The Economic Journal, Vol. 96, pp. 47. ISSN 0013-0133. DOI 10.2307/2232969.

[7] Christensen, L. R., Jorgenson, D. W. and Lau, L. J. (1975) "Transcendental Logarithmic Utility Functions", The American Economic Review, Vol. 65, No. 3, pp. 367-383. ISSN 0002-8282.

[8] Clements, K. W. and Si, J. (2016) "Price Elasticities of Food Demand: Compensated vs Uncompensated", Health Economics, Vol. 25, No. 11, pp. 1403-1408. ISSN 1057-9230. DOI 10.1002/hec.3226.

[9] Clonan, A., Wilson, P., Swift, J. A., Leibovici, D. G. and Holdsworth, M. (2015) "Red and processed meat consumption and purchasing behaviours and attitudes: impacts for human health, animal welfare and environmental sustainability", Public Health Nutrition, Vol. 18, No. 13, pp. 2446-2456. ISSN 1368-9800. DOI 10.1017/S1368980015000567. 
[10] Colen, L., Melo, P. C., Abdul-Salam, Y., Roberts, D., Mary, S. and Gomez Y Paloma, S. (2018) "Income elasticities for food, calories and nutrients across Africa: A meta-analysis", Food Policy, Vol. 77, No. May, pp. 116-132. ISSN 0306-9192. DOI 10.1016/j.foodpol.2018.04.002.

[11] Cook, E. (2018) "Agriculture, forestry and fishery statistics", 2018 ed., Brussels, Publications Office of the EU. ISBN 978-92-79-94757-5. ISSN 2363-2488. DOI 10.2785/340432.

[12] Cupák, A., Pokrivčák, J. and Rizov, M. (2015) "Food demand and consumption patterns in the new EU member states: The case of Slovakia", Ekonomicky Casopis, Vol. 63, No. 4, pp. 339-358. ISSN 0013-3035.

[13] Czech Statistical Office (2020) "Meat consumption statistics by income deciles". [Online]. Available: https://www.czso.cz/csu/czso/statisticka-rocenka-ceske-republiky-2020 [Acessed: Jan 15, 2021].

[14] Darnell, A. C. (1994) "A Dictionary of Econometrics", Edward Elgar Pub. ISBN 9781852783891.

[15] De Agostini, P. (2014) "The effect of food prices and household income on the British diet", ISER Working Paper Series, Vol. 2014, No. 1. E-ISSN 2435-0982.

[16] De Backer, C. J. S. and Hudders, L. (2015) "Meat morals: relationship between meat consumption consumer attitudes towards human and animal welfare and moral behavior", Meat Science, Vol. 99, pp. 68-74. ISSN 0309-1740. DOI 10.1016/j.meatsci.2014.08.011.

[17] De Zhou, Yu, X., Abler, D. and Chen, D. (2018) "Projecting meat and cereals demand for China based on a meta-analysis of income elasticities", China Economic Review, No. Dec., pp. 1-15. ISSN 1043-951X. DOI 10.1016/j.chieco.2017.12.002.

[18] Deaton, A. and Muellbauer, J. (1980) "An Almost Ideal Demand System", The American Economic Review, Vol. 70, No. 3, pp. 312-326. ISSN 0002-8282.

[19] Dickey, D. A. and Fuller, W. A. (1979) "Distribution of the Estimators for Autoregressive Time Series With a Unit Root", Journal of the American Statistical Association, Vol. 74, No. 366, pp. 427-431. ISSN 0162-1459. DOI 10.2307/2286348.

[20] Dubihlela, D. (2014) "The Impact Of Price Changes On Demand Among Poor Households In A South African Township", Vol. 13, No. 3. ISSN 1535-0754. DOI 10.19030/iber.v13i3.8586.

[21] Engle, R. F. and Granger, C. W. J. (1987) "Co-Integration and Error Correction: Representation, Estimation, and Testing", Econometrica, Vol. 55, No. 2, pp. 251-276. ISSN 0012-9682. DOI $10.2307 / 1913236$.

[22] Etemadi, A., Sinha, R., Ward, M. H., Graubard, B. I., Inoue-Choi, M., Dawsey, S. M. and Abnet, C. C. (2017) "Mortality from different causes associated with meat, heme iron, nitrates, and nitrites in the NIH-AARP Diet and Health Study: population based cohort study", BMJ-British Medical Journal. ISSN 1756-1833. DOI 10.1136/bmj.j1957.

[23] Euromonitor International (2018) "Processed Meat and Seafood in Czech Republic", Passport, No. Nov. [Online]. Available: http://www.portal.euromonitor.com.ez.unisabana.edu.co/portal/ analysis/tab. [Acessed: Jan 15, 2021].

[24] Farchi, S., De Sario, M., Lapucci, E., Davoli, M. and Michelozzi, P. (2017) "Meat consumption reduction in Italian regions: Health co-benefits and decreases in GHG emissions", PLoS ONE, Vol. 12, No. 8, pp. 1-20. ISSN 1932-6203. DOI 10.1371/journal.pone.0182960.

[25] Gallant, A. R. (1981) "On the bias in flexible functional forms and an essentially unbiased form", Journal of Econometrics, Vol. 15, No. 2, pp. 211-245. ISSN 0304-4076. DOI 10.1016/0304-4076(81)90115-9.

[26] Gerber, P. J., Steinfeld, H., Henderson, B., Mottet, A., Opio, C., Dijkman, J., Falcucci, A. and Tempio, G. (2013) "Tackling climate change through livestock - A global assessment of emissions and mitigation opportunities", Food and Agriculture Organization of the United Nations (FAO), Rome. E-ISBN 978-92-5-107921-8, ISBN 978-92-5-107920-1. [Online]. Available: http://www.fao. org/3/i3437e/i3437e00.htm [Acessed: Jan 10, 2021]. 
[27] Godfray, H. C. J., Aveyard, P., Garnett, T., Hall, J. W., Key, T. J., Lorimer, J., Pierrehumbert, R. J., Scarborough, P., Springmann, M. and Jebb, S. A. (2018) "Meat consumption, health, and the environment", Science (New York, N.Y.), Vol. 361, No. 6399. ISSN 0036-8075. DOI 10.1126/science.aam5324.

[28] Green, R., Cornelsen, L., Dangour, A. D., Honorary, R. T., Shankar, B., Mazzocchi, M. and Smith, R. D. (2013) "The effect of rising food prices on food consumption: systematic review with meta-regression", BMJ-British Medical Journal, Vol. 347, No. 7915, pp. 1-9. ISSN 1756-1833. DOI 10.1136/bmj.f3703.

[29] Hálová, P. (2006) "The analysis of consumer behavior with Törnquist functions using for choice food products", In Agrarian Perspectives XV - Foreign trade and globalization processes, pp. 168-173.

[30] Hálová, P. (2015) "Analysis of flowers production and consumption determinants in Czech Republic", Acta Universitatis Agriculturae et Silviculturae Mendelianae Brunensis, Vol. 63, No. 3, pp. 903-913. ISSN 1221-8516. DOI 10.11118/actaun201563030903.

[31] Harding, M. and Lovenheim, M. (2017) "The effect of prices on nutrition: Comparing the impact of product- and nutrient-specific taxes", Journal of Health Economics, Vol. 53, pp. 53-71. ISSN 0167-6296. DOI 10.1016/j.jhealeco.2017.02.003.

[32] Hovhannisyan, V. and Gould, B. W. (2014) "Structural change in urban Chinese food preferences", Agricultural Economics, Vol. 45, No. 2, pp. 159-166. ISSN 0169-5150. DOI 10.1111/agec.12038.

[33] Hupková, D., Bielik, P. and Turčeková, N. (2009) "Structural changes in the beef meat demand in Slovakia and demand elasticity estimation", Agricultural Economics - Czech, Vol. 55, No. 8, pp. 361-367. ISSN 0139-570X. DOI 10.17221/41/2009-AGRICECON.

[34] Jarque, C. M. and Bera, A. K. (1980) "Efficient tests for normality, homoscedasticity and serial independence of regression residuals", Economics Letters, Vol. 6, No. 3, pp. 255-259. ISSN 0165-1765. DOI 10.1016/0165-1765(80)90024-5.

[35] Konig, B. and Dovadova, G. (2016) "Trends in household consumption inequalities in Slovakia: Empirical evidence", Ekonomicky Casopis, Vol. 64, No. 3, pp. 238-259. ISSN 0013-3035.

[36] Kubicová, L., Kádeková, Z., Nagyová, L'. and Stávková, J. (2011) "The Income situation of the private households and its impact on the food consumption in the Slovak Republic", Acta Universitatis Agriculturae et Silviculturae Mendelianae Brunensis, Vol. 59, No. 7, pp. 217-224. ISSN 1221-8516. DOI 10.11118/actaun201159070217.

[37] Kučerová, V. and Zeman, J. (2013) "Cenová elasticita poptávky jako nástroj pro plánování úspěšných akčních slev Price Elasticity of Demand as a Tool for Planning of Successful Promotional Discounts", Trendy Ekonomiky a Managementu, Vol. VII, No. 17, pp. 101-113. ISSN 1802-8527. (In Czech).

[38] Li, L., Song, Z. and Ma, C. (2015) "Engel curves and price elasticity in urban Chinese Households", Economic Modelling, Vol. 44, pp. 236-242. ISSN 0264-9993. DOI 10.1016/j.econmod.2014.10.002.

[39] Lundberg, J. and Lundberg, S. (2012) "Distributional Effects of Lower Food Prices in a Rich Country: Calculations Based on Estimates of Household Demand for Food", Journal of Consumer Policy, Vol. 35, No. 3, pp. 373-391. ISSN 0168-7034. DOI 10.1007/s10603-012-9193-X.

[40] Marquer, P., Rabade, T. and Forti, R. (2015) "Meat production statistics", Brussels. [Online]. Available: https://ec.europa.eu/eurostat/statistics-explained/pdfscache/28947.pdf. [Acessed: Jan 10, 2021].

[41] Mathijs, E. (2015) "Exploring future patterns of meat consumption", Meat Science, Vol. 109, pp. 112-116. ISSN 0309-1740. DOI 10.1016/j.meatsci.2015.05.007.

[42] Mekonnen, M. M. and Hoekstra, A. Y. (2012) "A Global Assessment of the Water Footprint of Farm Animal Products", Ecosystems, Vol. 15, No. 3, pp. 401-415. ISSN 1432-9840. DOI 10.1007/s10021-011-9517-8. 
[43] Melina, V., Craig, W. and Levin, S. (2016) "Position of the Academy of Nutrition and Dietetics: Vegetarian Diets", Journal of the Academy of Nutrition and Dietetics, Vol. 116, No. 12, pp. 1970-1980. ISSN 2212-2672. DOI 10.1016/j.jand.2016.09.025.

[44] Milford, A. B., Le Mouël, C., Bodirsky, B. L. and Rolinski, S. (2019) "Drivers of meat consumption", Appetite, Vol. 141, No. June. ISSN 0195-6663. DOI 10.1016/j.appet.2019.06.005.

[45] Ministry of Agriculture (2020) "The statistical report of the Czech agriculture", Prague: Ministry of Agriculture, internal document.

[46] Mizdrak, A., Scarborough, P., Waterlander, W. E. and Rayner, M. (2015) "Differential responses to food price changes by personal characteristic: A systematic review of experimental studies", PLoS ONE, Vol. 10, No. 7, pp. 1-20. ISSN 1932-6203. DOI 10.1371/journal.pone.0130320.

[47] Muhammad, A., D'Souza, A., Meade, B., Micha, R. and Mozaffarian, D. (2017) "How income and food prices influence global dietary intakes by age and sex: evidence from 164 countries", $B M J$ Global Health, Vol. 2, No. 3. ISSN 2059-7908. DOI 10.1136/bmjgh-2016-000184.

[48] Niebylski, M. L., Redburn, K. A., Duhaney, T. and Campbell, N. R. (2015) "Healthy food subsidies and unhealthy food taxation: A systematic review of the evidence", Nutrition, Vol. 31, No. 6, pp. 787-795. ISSN 0899-9007. DOI 10.1016/j.nut.2014.12.010.

[49] Norton, E. (2020) "UK meat consumption. The UK consumes more beef than a decade ago". [Online]. Available: https://www.savills.co.uk/research_articles/229130/298951-0. [Acessed: Jan 15, 2021].

[50] OECD (2020) "Meat consumption". [Online]. Available at https://data.oecd.org/agroutput/meatconsumption.htm. [Acessed: Jan 15, 2021].

[51] Pearce, D. W. (ed.) (1986) "Macmillan Dictionary of Modern Economics", London: Macmillan Education UK. ISBN 9780333417485. DOI 10.1007/978-1-349-18424-8.

[52] Popkin, B. M. (2006) "Global nutrition dynamics: the world is shifting rapidly toward a diet linked with noncommunicable diseases", The American Journal of Clinical Nutrition, Vol. 84, No. 2, pp. 289-298. ISSN 0002-9165. DOI 10.1093/ajcn/84.2.289.

[53] Regmi, A. and Meade, B. (2013) "Demand side drivers of global food security", Global Food Security, Vol. 2, No. 3, pp. 166-171. ISSN 2211-9124. DOI 10.1016/j.gfs.2013.08.001.

[54] Ren, Y., Zhang, Y., Loy, J.-P. and Glauben, T. (2018) "Food consumption among income classes and its response to changes in income distribution in rural China", China Agricultural Economic Review, Vol. 10, No. 3, pp. 406-424. ISSN 1756-137X. DOI 10.1108/CAER-08-2014-0079.

[55] Rohrmann, S., Overvad, K., Bueno-de-Mesquita, H. B., Jakobsen, M. U., Egeberg, R., Tjønneland, A., ... Linseisen, J. (2013) "Meat consumption and mortality - results from the European Prospective Investigation into Cancer and Nutrition", BMC Medicine, Vol. 11, No. 1, 63 p. ISSN 1741-7015. DOI 10.1186/1741-7015-11-63.

[56] Salotti, S., Montinari, L., Amores, A. F. and Rueda-Cantuche, J. M. (2015) "Total expenditure elasticity of non-durable consumption of European households", European Union: JRC Technical Report EUR 27081 EN.

[57] Santeramo, F. G., Carlucci, D., De Devitiis, B., Seccia, A., Stasi, A., Viscecchia, R. and Nardone, G. (2018) "Emerging trends in European food, diets and food industry", Food Research International, Vol. 104, No. October 2017, pp. 39-47. ISSN 0963-9969. DOI 10.1016/j.foodres.2017.10.039.

[58] Smed, S., Jensen, J. D. and Denver, S. (2007) "Socio-economic characteristics and the effect of taxation as a health policy instrument", Food Policy, Vol. 32, No. 5-6, pp. 624-639. ISSN 0306-9192. DOI 10.1016/j.foodpol.2007.03.002.

[59] Spicka, J. (2016) "Market Concentration and Profitability of the Grocery Retailers in Central Europe", Central European Business Review, Vol. 5, No. 3, pp. 5-24. ISSN 1805-4854. DOI $10.18267 /$ j.cebr. 155 . 
[60] Spicka, J. and Naglova, Z. (2017) "Consumers' preference of quality and pice in buying meat and meat products", Maso, Vol. 28, No. 1, pp. 50-54. ISSN 1210-4086.

[61] Springmann, M., Mason-D'Croz, D., Robinson, S., Wiebe, K., Godfray, H. C. J., Rayner, M. and Scarborough, P. (2018) "Health-motivated taxes on red and processed meat: A modelling study on optimal tax levels and associated health impacts", PLoS ONE, Vol. 13, No. 11, pp. 1-16. ISSN 1932-6203. DOI 10.1371/journal.pone.0204139.

[62] Steenhuis, I. H., Waterlander, W. E. and de Mul, A. (2011) "Consumer food choices: the role of price and pricing strategies", Public Health Nutrition, Vol. 14, No. 12, pp. 2220-2226. ISSN 1368-9800. DOI $10.1017 /$ S1368980011001637.

[63] Syrovátka, P. (2012) "Income elasticity of demand within individual consumer groups and the level of income elasticity of the entire market demand", Agricultural Economics - Czech, Vol. 52, No. No. 9, pp. 412-417. ISSN 0139-570X. DOI 10.17221/5044-AGRICECON.

[64] Thow, A. M., Jan, S., Leeder, S. and Swinburn, B. (2010) "The effect of fiscal policy on diet, obesity and chronic disease: a systematic review", Bulletin of the World Health Organization, Vol. 88, No. 8, pp. 609-614. ISSN 0042-9686. DOI 10.2471/BLT.09.070987.

[65] Tiffin, R. and Arnoult, M. (2010) "The demand for a healthy diet: estimating the almost ideal demand system with infrequency of purchase", European Review of Agricultural Economics, Vol. 37, No. 4, pp. 501-521. ISSN 0165-1587. DOI 10.1093/erae/jbq038.

[66] Tiffin, R. and Arnoult, M. (2011) "The public health impacts of a fat tax", European Journal of Clinical Nutrition, Vol. 65, No. 4, pp. 427-433. ISSN 0954-3007. DOI 10.1038/ejcn.2010.281.

[67] Tiffin, R., Balcombe, K., Salois, M. and Kehlbacher, A. (2011) "Estimating Food and Drink Elasticities", University of Reading. [Online]. Available: https://www.gov.uk/government/ uploads/system/uploads/attachment\%7B_\%7Ddata/file/137726/defra-stats-foodfarm-food-priceelasticities-120208.pdf\%5Cnhttps://www.gov.uk/government/uploads/system/uploads/attachment data/file/137726/defra-stats-foodfarm-food-pr. [Acessed: Jan 8, 2021].

[68] Türkekul, B. and Unakitan, G. (2011) "A co-integration analysis of the price and income elasticities of energy demand in Turkish agriculture", Energy Policy, Vol. 39, No. 5, pp. 2416-2423. ISSN 0301-4215. DOI 10.1016/j.enpol.2011.01.064.

[69] Ulubasoglu, M., Mallick, D., Wadud, M., Hone, P. and Haszler, H. (2015) "Food demand elasticities for Australia", The Australian Journal of Agricultural and Resource Economics, Vol. 60, No. 2, pp. 177-195. ISSN 1364-985X. DOI 10.1111/1467-8489.12111.

[70] Vranken, L., Avermaete, T., Petalios, D. and Mathijs, E. (2014) "Curbing global meat consumption: Emerging evidence of a second nutrition transition", Environmental Science \& Policy, Vol. 39, No. May 20, pp. 95-106. ISSN 1462-9011. DOI 10.1016/j.envsci.2014.02.009.

[71] Wang, X., Lin, X., Ouyang, Y. Y., Liu, J., Zhao, G., Pan, A. and Hu, F. B. (2016) "Red and processed meat consumption and mortality: dose-response meta-analysis of prospective cohort studies", Public Health Nutrition, Vol. 19, No. 5, pp. 893-905. ISSN 1368-9800. DOI 10.1017/S1368980015002062.

[72] Wohlgenant, M. K. (1984) "Conceptual and Functional Form Issues in Estimating Demand Elasticities for Food", American Journal of Agricultural Economics, Vol. 66, No. 2, pp. 211-215. ISSN 0002-9092. DOI 10.2307/1241045.

[73] Wolk, A. (2017) "Potential health hazards of eating red meat", Journal of Internal Medicine, Vol. 281, No. 2, pp. 106-122. ISSN 0954-6820. DOI 10.1111/joim.12543. 